\title{
THE COMPARISON OF USEFULNESS RESULTS OF THE PRIMIPAROUS AND MULTIPAROUS CATTLE OF THE LIMOUSINE BREED
}

\section{PORÓWNANIE WYNIKÓW UŻYTKOWOŚCI PIERWIASTEK I WIELORÓDEK BYDŁA RASY LIMOUSINE}

\author{
Department of Ruminant Science, West Pomeranian University of Technology, Szczecin, Poland
}

\begin{abstract}
Streszczenie. Badania przeprowadzono w stadzie bydła rasy limousine, utrzymywanego w czystości rasy, w województwie kujawsko-pomorskim. Badaniami objęto łącznie 107 osobników - 27 pierwiastek i 80 wieloródek. Dane dotyczące krów uzyskano z dokumentacji hodowlanej prowadzonej w gospodarstwie, zgodnie z wytycznymi Polskiego Związku Hodowców i Producentów Bydła Mięsnego z lat 2013-2014. Celem pracy było porównanie wyników użytkowości pierwiastek i wieloródek bydła rasy limousine. W pracy uwzględniono wybrane pomiary zoometryczne oraz wskaźniki płodności i mleczności krów, jak również ocenę wyników odchowu cieląt. Analiza wykazała istotne różnice ( $P \leq 0,01, P \leq 0,05$ ) w przypadku umięśnienia, obwodu klatki piersiowej i wysokości w krzyżu. Większe wartości wymienionych parametrów uzyskały pierwiastki. Stwierdzono wyższą produkcyjność mleka u krów pierwiastek, czego wynikiem były lepsze przyrosty ich cieląt. Wiek pierwszego wycielenia (WPW) w porównywanych grupach zwierząt był zbliżony. Cielęta po wieloródkach charakteryzowały się większą masą urodzeniową $(P \leq 0,01)$ niż cielęta po pierwiastkach.
\end{abstract}

Key words: limousine cattle, primiparous, multiparous, age at first calving, muscularity.

Słowa kluczowe: bydło rasy limousine, pierwiastki, wieloródki, wiek pierwszego wycielenia, umięśnienie.

\section{INTRODUCTION}

Limousine breed is a breed of large-custard cattle and has enjoyed great popularity among Polish breeders in recent years (Wróblewska et al. 2007). It belongs to the breeds used intensively and extensively. Animals of this breed are characterized by early adolescence, good fertility, longevity and easy leaks. In addition, the cattle have a well-developed maternal instinct and vivacious temperament (Wróblewska et al 2007; Grodzki 2008; Chów bydła mięsnego 2009). When choosing a breed of cattle for cattle, a very important aspect is the analysis of the usability. It allows you to get a lot of information about individual breeds and their fattening predispositions in given breeding system (Szewczyk 2005). According to Domaradzki et al. (2016) consumers are now expecting meat of high nutritional value, safe as well as high sensory value, meeting the assumptions of the so- Food convenient.

Corresponding author - Adres do korespondencji: Ewa Czerniawska-Piątkowska, Department of Ruminant Science, West Pomeranian University of Technology, Szczecin, Klemensa Janickiego 29, 71-270 Szczecin, Poland, e-mail: ewa.czerniawska-piatkowska@zut.edu.pl. 


\section{MATERIAL AND METHODS}

The study was carried out on a farm located in the Kujawsko-Pomorskie province keeping the limousine cattle. There were 315 purebred cattle in the breed. The study included a total of 107 individuals: 27 primiparous and 80 multiparous. Cattle data were obtained from the farm documentation maintained on the farm, in accordance with the guidelines of the Polish Federation of Breeders and Producers of Cattle (PZHiPBM) for the years 2013-2014. The following parameters of primiparous cows and multiparous cows were analyzed: mass of animals, cow shape, muscularity, height in the cross, chest circumference, first calving (WPW days), intercourse (OMW days), milking. In addition, body mass index and calf gain were estimated: birth weight $[\mathrm{kg}]$, standardized weight in 210 days [kg], daily gains in 210 days [g]. The data collected was statistically calculated using the Statistica ${ }^{\circledR} 12$ PL program. The significance of the differences was calculated by one-way analysis of variance, using Duncan's multiple-stretch test.

\section{RESULTS AND DISCUSSION}

Table 1 shows body weight results of multiparous cows and selected zoometric parameters of the primiparous limousine cattle. According to the results of the tests, the average body weight of the multiparous was $559.98 \mathrm{~kg}$. According to other authors, body weight of over $80 \%$ of the population of the limousine population was $450-650 \mathrm{~kg}$ (Stanek 2006a). In their own study (Table 1), the animal's habit was different - the primiparous was 25.62 points, and the cows' multiply - 23.19 points. Considering the results obtained by Wójcik et al. (2008) analyzing in their work the parameters of cows of different breeds, it was found that the limousine cows gained the most points for the breed (15.1). Analyzes of limousine musculature (Table 1) showed significant differences $(P \leq 0.05)$ between the examined group of primiparous and multiparous. Primiparous had a greater $(P \leq 0.05)$ number of points for muscular strength (17.92) compared to polyps (14.65). Wójcik et al. (2008) scored 7.2 points for limousine muscles in their study. This was the highest average for the breed (red angus 6.8 , salers -7.1 , hereford -6.8 , simon -6.8 ). Another feature described is the height in the cross (Table 1). In the own studies, the values $(P \leq 0.01)$ of the indicator in question were higher $(P \leq 0.01)$ in the case of the primiparous $(134.23 \mathrm{~cm})$ than in the case of $132.51 \mathrm{~cm}$. In his research, Stanek (2006b) analyzing the height of the cross of primiparous Hereford and Limousine breeds, found that limousine values ranged from 115 to $140 \mathrm{~cm}$, and hereford ranged from 113 to $142 \mathrm{~cm}$. Analyzing the results of multi-cow cows in relation to altitude in the cross, they were from 129 to $138 \mathrm{~cm}$. In the studies of Czerniawska-Piątkowska et al. (2014) limousine cows were characterized by higher mean crosses than cows of red angus (137.45 and $134.29 \mathrm{~cm}$, respectively). Also, Wójcik et al. (2008) for the limousine received an average of $136.6 \mathrm{~cm}$ high in the cross. Another feature analyzed in our own study (Table 1) was the perimeter of the thorax. This parameter for primiparous was at the level of $194.23 \mathrm{~cm}$ and the multiparous was lower $(P \leq 0.05)$ and was $192.83 \mathrm{~cm}$. Wójcik et al. (2008) achieved similar results, recording $192.7 \mathrm{~cm}$ in limousine cows. A comparable mean of $194.07 \mathrm{~cm}$ was obtained by Czerniawska-Piątkowska et al. (2012). 
Table 1. Body weight and selected zoometric measurements of limousine primiparous and multiparous Tabela 1. Masa ciała oraz wybrane pomiary zoometryczne pierwiastek i wieloródek bydła mięsnego rasy limousine

\begin{tabular}{|c|c|c|c|c|}
\hline \multirow{2}{*}{$\begin{array}{l}\text { Parameter } \\
\text { Badane parametry }\end{array}$} & \multicolumn{2}{|c|}{$\begin{array}{l}\text { Primiparous } \\
\text { Pierwiastki }\end{array}$} & \multicolumn{2}{|c|}{$\begin{array}{l}\text { Multiparous } \\
\text { Wieloródki }\end{array}$} \\
\hline & $\bar{x}$ & SD & $\bar{x}$ & SD \\
\hline $\begin{array}{l}\text { Body weight } \\
\text { Masa zwierząt [kg] }\end{array}$ & - & - & 559.98 & 25.56 \\
\hline $\begin{array}{l}\text { Conformation } \\
\text { Pokrój krowy [pt] }\end{array}$ & 25.62 & 1.04 & 23.19 & 4.47 \\
\hline $\begin{array}{l}\text { Muscularity } \\
\text { Umięśnienie [pt] }\end{array}$ & $17.92^{a}$ & 0.95 & $14.65^{a}$ & 4.47 \\
\hline $\begin{array}{l}\text { Height of lower back } \\
\text { Wysokość } \\
\text { w krzyżu [cm] }\end{array}$ & $134.23^{\mathrm{A}}$ & 2.05 & $132.51^{\mathrm{A}}$ & 1.74 \\
\hline $\begin{array}{l}\text { Chest girth } \\
\text { Obwód klatki } \\
\text { piersiowej [cm] }\end{array}$ & $194.23^{b}$ & 2.09 & $192.83^{b}$ & 2.66 \\
\hline
\end{tabular}

The age of first calving (WPW) of the primiparous (Table 2) was 952 days (31.3 months). The multiiparous cows were shorter (30.6 months). Other results were obtained by Stanek (2006a). The first calving of cows in the tested herd was recorded between 23 and 26 months of age. This result was obtained by $42.3 \%$ of heifers. Another $20.4 \%$ calved In the age of 28 to 33 months, they were $20.4 \%$. Extreme values, ie those that fell below 23 months, were only $5.7 \%$ and $10.5 \%$ above the third year of life. Well-heared heifers can be hatched at the age of 15 months. In this case, the calving takes place at the age of 2, which allows to maintain the proper seeding season with good use of pasture (Przysucha and Grodzki 2007a, b). The interplanar period in the multiparous of the stock evaluated (Table 2) was 572 days (18.6 months). Czerniawska-Piątkowska et al. (2014) report that the intercourse period of the limousine cows in the herd tested lasted an average of 493.29 days. Przysucha et al. (2002) by analyzing fertility rates of red angus and hereford, the mean OMW was 397.9 days for red angus and 392.6 days for hereford. Dairy cows in the analyzed herd: primiparous and multiparous (Table 2) were $1951.41 \mathrm{~kg}$ and $1915.26 \mathrm{~kg}$, respectively. Other authors obtained $1512.4 \mathrm{~kg}$ for the primiparous and $1637.8 \mathrm{~kg}$ for the multiparous. Differences were significant ( $P \leq 0.01$ ) (Litwińczuk and Shulc 2005). As Choroszy et al. (2011) the average milk yield of cows of limousine ranged from $1843.2 \mathrm{~kg}$ to $2069.2 \mathrm{~kg}$. Of the breeds tested, the highest milk yield was given to charolais cows (from 1930 to $2186 \mathrm{~kg}$ ).

In analyzing body mass index of calf of primiparous and multiparous weight gain in the limousine (Table 3), it was found that the weight of the calves from the primiparous was $29.85 \mathrm{~kg}$ and was lower $(P \leq 0.01)$ than the calves from the multiparous $-31.40 \mathrm{~kg}$. Other authors in their work have proven that the order of calving affects the calf's birth weight. The limousine elements gave birth to purebred calves with a mean body weight of $31.37 \mathrm{~kg}$. With 
subsequent births, the tendency of body mass was observed (Wróblewska et al. 2007). As in the cited authors' analysis, the analysis has shown the highly significant influence of the order of incarnation on the mass of newborns. Litwińczuk and Szulc (2005) received different results. At the primiparous, this parameter was $32.1 \mathrm{~kg}$ and for multiparous was $31.4 \mathrm{~kg}$.

Table 2. Selected fertility and milking indexes and limousine primiparous and multiparous Tabela 2. Wybrane wskaźniki płodności i mleczność pierwiastek oraz wieloródek bydła mięsnego rasy limousine

\begin{tabular}{|c|c|c|c|c|}
\hline \multirow{2}{*}{$\begin{array}{c}\text { Parameter } \\
\text { Badane parametry }\end{array}$} & \multicolumn{2}{|c|}{$\begin{array}{c}\text { Primiparous } \\
\text { Pierwiastki }\end{array}$} & \multicolumn{2}{|c|}{$\begin{array}{l}\text { Multiparous } \\
\text { Wieloródki }\end{array}$} \\
\hline & $\bar{x}$ & SD & $\bar{x}$ & SD \\
\hline $\begin{array}{l}\text { Age at first calving } \\
\text { [days/months] } \\
\text { Wiek pierwszego wycielenia } \\
\text { [dni/mies.] }\end{array}$ & $952 / 31.3$ & 84.36 & $932 / 30.6$ & 136.63 \\
\hline $\begin{array}{l}\text { Calving interval } \\
\text { [days/months] } \\
\text { Okres międzywycieleniowy } \\
\text { [dni/mies.] }\end{array}$ & - & - & $567 / 18.6$ & 159.59 \\
\hline Milk yield - Mleczność [kg] & 1951.41 & 216.84 & 1915.26 & 149.49 \\
\hline
\end{tabular}

Table 3. Body weight and calf-derived calves derived from limousine primiparous and multiparous Tabela 3. Wskaźniki masy ciała oraz przyrosty cieląt pochodzących od pierwiastek i wieloródek rasy limousine

\begin{tabular}{|c|c|c|c|c|}
\hline \multirow{2}{*}{$\begin{array}{c}\text { Parameters } \\
\text { Badane parametry }\end{array}$} & \multicolumn{2}{|c|}{$\begin{array}{l}\text { Primiparous } \\
\text { Pierwiastki }\end{array}$} & \multicolumn{2}{|c|}{$\begin{array}{l}\text { Multiiparous } \\
\text { Wieloródki }\end{array}$} \\
\hline & $\bar{x}$ & SD & $\bar{x}$ & SD \\
\hline $\begin{array}{l}\text { Birth weight of calves } \\
\text { Masa urodzeniowa cieląt [kg] }\end{array}$ & $29.85^{\mathrm{A}}$ & 0.66 & $31.40^{\mathrm{A}}$ & 1.88 \\
\hline $\begin{array}{l}\text { Weaning weight in 210th day } \\
\text { Masa standaryzowana w } 210 \text { dniu [kg] }\end{array}$ & 239.44 & 24.11 & 231.95 & 35.22 \\
\hline $\begin{array}{l}\text { Daily gain in } 210 \text { th day } \\
\text { Przyrosty w } 210 \text { dniu [g] }\end{array}$ & 997.55 & 115.57 & 974.68 & 79.65 \\
\hline
\end{tabular}

A the average marked in lines in different letters differs significantly $\mathrm{P} \leq 0.01$ - średnie oznaczone w wierszach dużą literą różnią się istotnie przy $\mathrm{P} \leq 0,01$.

The result was $239.44 \mathrm{~kg}$ for the primiparous and $231.95 \mathrm{~kg}$ in the multiparous. Litwińczuk and Szulc (2005) report that primiparous limousine calves gained $218.9 \mathrm{~kg}$ and $233.8 \mathrm{~kg}$ multiparous $(P \leq 0.01)$.

The results showed that the increase in 210 days of life (Table 3 ) was at the following level: the calves from primiparous cows were growing at an average of 997.55 grams per day and $974.68 \mathrm{~kg}$ in the multiparous. In studies by Litwińczuk et al. (2005) analyzing calf growth at 210 days for limousine and hereford, the limousine primiparous yielded $889.6 \mathrm{~g}$ and $963.4 \mathrm{~g}$ multiparous ( $\mathrm{P} \leq 0.01)$. For Hereford, the following results were obtained: $759.9 \mathrm{~g}, 766.3 \mathrm{~g}$. 


\section{CONCLUSIONS}

1. Comparing the results of zoometric measurements of primiparous cows and multiparous showed a more favorable effect on the muscular and chest circumference of the primiparous. Differences were significant $(P \leq 0.05)$.

2. A higher value of the height index in the cross at the primiparous has been shown. Differences were significant $(P \leq 0.01)$.

3. Age of first calving (WPW) in the groups of animals was similar and was 31.3 months in the primiparous and 30.6 months in the multiparous.

4. Higher milk production was found in the cows' primiparous, resulting in better growth of their calves.

5. The higher birth weight of calves in cows' multiparous was compared to the primiparous. Differences were significant $(P \leq 0.01)$.

\section{REFERENCES}

Choroszy Z., Choroszy B., Łopieńska M., Szewczyk A., Grodzki G. 2011. Analiza preparatów wzrostu cieląt rasy Limousine, Charolaise i Hereford w stadach hodowlanych objętych kontrolą użytkowości [Analysis of Limousine, Charolaise and Hereford calf growths in control flocks]. Rocz. Nauk. Zootech. 38(2), 137-147. [in Polish]

Chów bydła mięsnego. 2009. Red. H. Grodzki. Poznań, Wielkopol. Wydaw. Rol., 186. [in Polish]

Czerniawska-Piątkowska E., Cioch B., Hołubowski P., Bartyzel B.J. 2014. Porównanie wybranych wskaźników rozrodczych i parametrów zoometrycznych krów ras Limousine i Red Angus [Comparison of selected reproductive parameters and zoometric parameters of Limousine and Red Angus cows]. Zesz. Nauk. Univ. Przyr. Wroc. 73(602), 23-30. [in Polish]

Czerniawska-Piątkowska E., Szewczuk M., Chociłowicz E., Konstancik N. 2012. comparison of limousin and simmental primiparous cows based on the variability of age at first calving, body weight and the analysis of their growth and development. Electron. J. Pol. Agric. Univ. 15(2), access: http://www.ejpau.media.pl/volume15/issue2/abs-07.html.

Domaradzki P., Florek M., Litwińczuk A. 2016. Czynniki kształtujące jakość mięsa wołowego. Wiadomości Zootechniczne [Factors shaping the quality of beef]. Wiad. Zootech. 54(2), 160-170. [in Polish]

Grodzki H. 2008. Alfabet ras bydła mięsnego. Limousine [The alphabet of cattle breeds of meat. Limousine]. Bydło 5, 36-37. [in Polish]

Litwińczuk Z., Szulc T. 2005. Hodowla i użytkowanie bydła. Warszawa, PWRiL. [in Polish]

Przysucha T., Grodzki H. 2007a. Porównanie wyników oceny użytkowości czystorasowej i mieszańcowej populacji francuskich ras bydła mięsnego [Comparison of recording results of purebred and crossbred beef cattle of French origin]. Acta Sci. Pol., Zootech. 6(3), 43-50. [in Polish]

Przysucha T., Grodzki H. 2007b. Zależność między wiekiem i rasą jałówek mięsnych a przebiegiem porodów [Relationship between age and race of meat heifers and the course of deliveries]. Med. Weter. 63(12), 1576-1578.

Przysucha T., Grodzki H., Czarnecki vel Sarnecki M., Slósarz J. 2002. Wpływ sezonu i kolejności ocielenia na wybrane wskaźniki płodności ras angus i hereford [An effect of season and number of calving on the selected fertility indices in Angus and Hereford breeds]. Zesz. Nauk. Prz. Hod. 62, 253-259. [in Polish]

Stanek P. 2006a. Zmienność wieku pierwszego wycielenia, masy i wymiarów ciała krów rasy limousine i hereford. Wiek pierwszego wycielenia i masa ciała [Variability of age of first calving, mass and body dimensions of limousine cows and hereford. Age of first calving and body weight]. Ann. UMCS, Sec. EE 24(11), 73-79. [in Polish] 
Stanek P. 2006b. Zmienność wieku pierwszego wycielenia, masy i wymiarów ciała krów rasy limousine i hereford. Wymiary ciała [Variability of age of first calving, mass and body dimensions of limousine cows and hereford. Body dimensions]. Ann. UMCS, Sec. EE 24(12), 81-87. [in Polish]

Szewczyk A. 2005. Charakterystyka wybranych ras bydła mięsnego. Cz. I. [Characteristics of selected cattle breeds. Part I]. Hod. Bydła 2, 40-45. [in Polish]

Wójcik J., Pilarczyk R., Jasiński A., Piłat D. 2008. Comparison of growth and development in cows of different meat breeds in the Western Pomerania area based on parameterized results. Ann. Anim. Sci. 8(1), 13-22.

Wróblewska L., Zdziarski K., Maruska J. 2007. Wpływ wybranych czynników na łatwość ocieleń i masę ciała cieląt rasy limousine i mieszańców z jej udziałem [Effect of selected factors on the ease of body weight and body weight of calves of limousine and hybrids with its participation]. Ann. UMCS, Sec. EE 25(1), 15-20. [in Polish]

Abstract. The study was conducted in a herd of cattle kept in pure breed in the Kujawsko-Pomorskie province. The study included a total of 107 individuals: 27 primiparous and 80 multiparous. Cattle data were obtained from farm documentation maintained on the farm, in accordance with the guidelines of the Polish Association of Breeders and Producers of Cattle (PZHiPBM) for the years 2013-2014. The aim of the study was to compare the performance of primiparous and multiparous of limousine cattle. The work included selected zoometric measurements, fertility and dairy cows as well as calf rearing. Analysis showed significant differences $(P \leq 0.01, P \leq 0.05)$ in the case of muscle, chest circumference and height of the cross. The higher values for the given parameters were obtained by the primiparous. It has been found that milk production is higher in primiparous cows, which results in better growth of calves. The age of first calving (WPW) in the groups of animals was similar. The calves after multiparous received a higher birth weight $(P \leq 0.01)$ compared with calves after the primiparous. 